\title{
Activation and Characterization of Trypsin-Treated Lipase
}

\section{Ziqin Liu and Huihua Huang*}

Department of Food Science and Technology, South China University of Technology, Wushan Road 381, Guangzhou 510641, China

\begin{abstract}
Effect of trypsin hydrolysis on lipase in activation, characteristics and change in thermal stability were studied. Lipase was found to be increased in activity from $584 \mathrm{U} \mathrm{mL}^{-1}$ to $759 \mathrm{U} \mathrm{mL}^{-1}$ via trypsin treatment at the concentration of $1.5 \mathrm{mg} \mathrm{mL}^{-1}, 30^{\circ} \mathrm{C}$ and $\mathrm{p}^{\mathrm{H}} 7.0$ for $30 \mathrm{~min}$. The trypsin-treated lipase showed a lower $\mathrm{K}_{\mathrm{m}}$ value $\left(79 \mathrm{mg} \mathrm{mL}^{-1}\right.$ olive oil substrate) than the native lipase $\left(100 \mathrm{mg} \mathrm{mL}^{-1}\right)$, indicating an improved affinity for olive oil substrate. The optimum $\mathrm{p}^{H}$ value of the trypsin-treated lipase maintained basically unchanged while the optimum temperature $\left(45^{\circ} \mathrm{C}\right)$ showed lower than the native lipase $\left(50^{\circ} \mathrm{C}\right)$. The half-inactivation time for the trypsin-treated lipase at $45^{\circ} \mathrm{C}, 50^{\circ} \mathrm{C}$ and $60^{\circ} \mathrm{C}$ was calculated as $131 \mathrm{~min}, 35.5 \mathrm{~min}$ and $4 \mathrm{~min}$ respectively, while for the native lipase at $50^{\circ} \mathrm{C}$ and $60^{\circ} \mathrm{C}$ was calculated as $128 \mathrm{~min}$ and $13 \mathrm{~min}$ respectively, indicating that the thermal stability of lipase is lowered after trypsin treatment.
\end{abstract}

Keywords: Trypsin-treated lipase; Activation; Thermal stability; Characterization

\section{Introduction}

Enzymes play more and more important roles in modern food industry and attract much attention for their potential industrial applications [1]. However, as a protein, enzyme is usually limited to its activity, stability and reaction conditions in catalytic reaction. Therefore, appropriate modification to increase the activity and stability of enzyme is essential for applications, such as genetic engineering, immobilization and/or process alterations, chemical modification of enzyme molecules [2]. As an effective modification method, limited hydrolysis can usually result in some beneficial change for an enzyme in chain and conformation and thus can alter the characteristics and functions of the enzyme. For examples, trypsinogen does not exhibit catalytic activity before a six-peptide is removed from the molecule via protease hydrolysis [3] and the activity of asparaginase can be increased four to five folds after its 10 or more amino acid residues are removed from its carboxyl terminal through trypsin hydrolysis [4,5].

As a hydrolases, lipase (triacylglycerol ester hydrolases, EC 3.1.1.3) catalyzes the hydrolysis of triglyceride to free fatty acids, diacylglycerol, monoglyceride and glycerol. Lipase also shows efficiency in various reactions such as ester synthesis, transesterification, interesterification, acidolysis and aminolysis in organic solvent or on support materials $[6,7]$, depending on the reaction conditions. Therefore, lipase is currently widely used in food industry, chemical, oleochemicals, agrochemical, paper making, washing, and synthesis of biosurfactants, biodiesel production and other industries $[8,9]$. Recently, some researchers have been carried out to improve lipase activity for extended applications, such as enzymatic hydrolysis, chemical modification, gene recombination and immobilization and so on $[6,10,11]$. The aim of this paper is to find out the effect of trypsin hydrolysis on the activity of lipase. Also the change of the trypsin-treated lipase, including the enzymatic properties and thermal stability are characterized.

\section{Materials and Methods}

\section{Materials}

Lipase Palatase 20000L was purchased from Novozymes Company $584 \pm 13 \mathrm{U} \mathrm{mL}^{-1}$, from Aspergillus oryzae, Novozymes Switzerland AG, Dittengen, Switzerland. ) and trypsin was purchased from SigmaAldrich Company $\left(2500 \pm 30 \mathrm{U} \mathrm{mg}^{-1}\right.$, from porcine pancreas, Sigma Chemical Co., Louis, USA).

\section{Activity assay of lipase}

One unit of lipase activity $(\mathrm{U})$ was defined as the enzyme amount required liberating $1 \mu \mathrm{mol}$ fatty acid per minute under the following assay conditions. Lipase activity assay was performed according to the olive oil emulsion method reported by Pawinee \& Suree [12]. The olive oil substrate was emulsified at 1:3 ratios with distilled water containing $2 \%(\mathrm{w} / \mathrm{v})$ polyvinyl alcohol in an ultrasonic sonicator. An ultrasonic homogenizer (model JY92-DN from Ningbo Scientz Biotechnology Co. LTD. Ningbo city, China) was used to generate an ultrasonic wave of $20 \mathrm{kHz}$ at $500 \mathrm{~W}$ and a tapered micro tip probe $(6 \mathrm{~mm}$ in diameter) was immersed into the sample solution at a $1.0-1.5 \mathrm{~cm}$ distance from the liquid level. A 3-3 second pulse-on mode and 6 min of total processing time were set. A reaction mixture was prepared with $4 \mathrm{~mL}$ olive oil emulsion substrate, $4 \mathrm{~mL}$ phosphate buffer $\left(\mathrm{p}^{\mathrm{H}} 7.5,0.05 \mathrm{~mol} \mathrm{~L}^{-1}\right)$ and $50 \mu \mathrm{L}$ lipase pre-heated at $37^{\circ} \mathrm{C}$ respectively and the hydrolysis was carried out at $37^{\circ} \mathrm{C}$ for $20 \mathrm{~min}$ in a water bath shaker at $180 \mathrm{r}$ min ${ }^{1}$. Hydrolysis reaction was terminated by adding $15 \mathrm{~mL}$ ethanol $(95 \%)$ to the reaction mixture. The liberated fatty acids were titrated against $\mathrm{NaOH}$ standard solution $\left(0.05 \mathrm{~mol} \mathrm{~L}^{-1}\right)$ with phenolphthalein as the indicator. The control experiments were performed under the same conditions with phosphate buffer substitute for enzyme.

\section{Treatment of lipase with trypsin}

$50 \mu \mathrm{L}$ of the lipase was incubated with $1 \mathrm{ml}$ trypsin solution at different concentrations $\left(0.5-4 \mathrm{mg} \mathrm{mL}^{-1}\right.$ dissolved in $\left.0.001 \mathrm{~mol} \mathrm{~L}^{-1} \mathrm{HCl}\right)$ and $4 \mathrm{~mL}$ of buffer $\left(0.05 \mathrm{~mol} \mathrm{~L}^{-1}, \mathrm{p}^{\mathrm{H}} 5.0-9.0\right)$ in a serial conical flasks at various temperatures $\left(25^{\circ} \mathrm{C}-50^{\circ} \mathrm{C}\right)$. After incubation for the scheduled time $(0-60 \mathrm{~min})$, the activity of the treated lipase was determined at 37 ${ }^{\circ} \mathrm{C}$ according to the method as described above. An equal volume of $0.001 \mathrm{molL}^{-1} \mathrm{HCl}$ was used as the blank. All experiments were carried out in triplicate.

*Corresponding author: Huihua Huang, Department of Food Science and Technology, South China University of Technology, Wushan Road 381,Guangzhou 510641, China, E-mail: fehhuang@scut.edu.cn

Received October 11, 2011; Accepted November 19, 2011; Published December 02, 2011

Citation: Liu Z, Huang H (2012) Activation and Characterization of Trypsin-Treated Lipase. J Food Process Technol 3:133. doi:10.4172/2157-7110.1000133

Copyright: @ 2012 Liu Z, et al. This is an open-access article distributed under the terms of the Creative Commons Attribution License, which permits unrestricted use, distribution, and reproduction in any medium, provided the original author and source are credited. 
To distinguish the hydrolysis effect of the trypsin on lipase from the hydrolysis effect of trypsin on the emulsified olive oil substrate hydrolysis, the same olive oil emulsion was used as substrate to incubate with the trypsin solution at $\mathrm{p}^{\mathrm{H}} 7.5$ and $37^{\circ} \mathrm{C}$ for $20 \mathrm{~min}$ in a water bath shaker at $180 \mathrm{rpm}$. After reaction, $15 \mathrm{~mL}$ ethanol (95\%) was added to the mixture to terminate trypsin activity and the liberated fatty acids were then titrated. All experiments were carried out in triplicate.

\section{Determination of Kinetic parameters}

The kinetic parameters of the trypsin-treated lipase and native lipase were determined according to the Lineweaver-Burk method. The kinetic constant value $\left(\mathrm{K}_{\mathrm{m}}\right)$ was determined according to the initial reaction rates of the trypsin-treated and native lipase at various concentrations of the emulsified olive oil substrate in phosphate buffer $\left(0.05 \mathrm{~mol} \mathrm{~L}^{-1}, \mathrm{p}^{\mathrm{H}} 7.0\right)$ at $37^{\circ} \mathrm{C}$ within 20 minutes. All experiments were carried out in triplicate. Lineweaver-Burk plots were constructed by plotting the reciprocal of the enzyme reaction velocity $\left(1 \mathrm{v}^{-1}\right)$ versus the reciprocal of the substrate concentration $\left(1[\mathrm{~S}]^{-1}\right)$. The Michaelis constant $\left(\mathrm{K}_{\mathrm{m}}\right)$ and maximum reaction velocity $\left(\mathrm{V}_{\max }\right)$ were obtained from the negative reciprocal of the intercept with the $1 \mathrm{~s}^{-1}$ axis and the reciprocal of the intercept with the $1 \mathrm{v}^{-1}$ axis, respectively.

\section{Comparation of thermal stability}

Change of the trypsin-treated lipase and native lipase in thermal stability was compared at $40^{\circ} \mathrm{C}, 45^{\circ} \mathrm{C}, 50^{\circ} \mathrm{C}$ and $60^{\circ} \mathrm{C}$ by determining the activity during the incubation from 1 to 90 minutes respectively. Thermal deactivation kinetics of the trypsin-treated lipase and native lipase was compared based on a single step first-order deactivation model and sequential deactivation model involving one and two intermediate states according to Sá-Pereira et al. [13]. The three-step deactivation model is expressed as

$$
\begin{array}{rlll}
\mathrm{K}_{1} & \alpha_{1} \mathrm{~K}_{2} & \alpha_{2} \\
E & \rightarrow & \mathrm{E}_{1} \rightarrow & \mathrm{E}_{2}
\end{array}
$$

Where $\mathrm{E}_{1} \mathrm{E}_{1}$ and $\mathrm{E}_{2}$ are the different enzyme states; $\mathrm{k}_{1}$ and $\mathrm{k}_{2}$ are the first-order deactivation rate coefficients; $\alpha_{1}$ and $\alpha_{2}$ are the ratio of the specific activity of $E_{1}$ and $E_{2}$ to the specific activity of $E$, respectively. According to Sá-Pereira et al. [13], two-step deactivation model can be adopted to simulate most of the enzyme thermal deactivation. In the case that $\alpha_{1}<1$, the intermediate state has a specific activity lower than the initial enzyme state; in the case that $\alpha_{1}=1$, the intermediate state is as active as the initial enzyme state; and in the case that $\alpha_{1}>1$, the intermediate state has a higher specific activity than the initial enzyme state. The similar consideration can be assumed for $\alpha_{2}$. If the contents of $\mathrm{E}_{1}$ and $\mathrm{E}_{2}$ are equal to zero at the beginning, the residual activity (a) at time $t$ can be expressed by

$$
\begin{aligned}
& a=\left(1+\frac{\alpha_{1} k_{1}-\alpha_{2} k_{2}}{k_{2}-k_{1}}\right) \exp \left(-k_{1} t\right)+ \\
& \frac{\left(\alpha_{2}-\alpha_{1}\right) k_{1}}{k_{2}-k_{1}} \exp \left(-k_{2} t\right)+\alpha_{2}
\end{aligned}
$$

In the case that $a_{2}=0$ and the enzyme state $E_{2}$ is completely deactivated and equal to the final enzyme state, the deactivation of enzyme conforms to the two-step deactivation model. The residual activity (a) can be expressed by

$$
a=\left(1+\frac{a_{1} k_{1}}{k_{2}-k_{1}}\right) \exp \left(-k_{1} t\right)-\frac{a_{1} k_{1}}{k_{2}-k_{1}} \exp \left(-k_{2} t\right)
$$

In the case that $\alpha_{1}=0$ and $E_{1}$ is the final state of the enzyme, the deactivation of enzyme conforms to the single step first-order deactivation model. The residual activity (a) can be expressed by

$$
a=\exp \left(-k_{1} t\right)
$$

\section{Results and Discussion}

\section{Effect of trypsin on the activity of lipase}

Lipase was found to be increased in activity from initial $584 \pm 13 \mathrm{U}$ $\mathrm{mL}^{-1}$ to maximum $759 \pm 15 \mathrm{U} \mathrm{mL}^{-1}$ after treatment of trypsin at $1.5 \mathrm{mg}$ $\mathrm{mL}^{-1}$ concentration at $30^{\circ} \mathrm{C}$ and $\mathrm{p}^{\mathrm{H}} 7.0$ for $30 \mathrm{~min}$ (Figure 1a). Such effect of trypsin on lipase activity is likely contributed to the results from the limited hydrolysis by lipase or the olive oil hydrolysis directly due to trypsin activity. To distinguish these two kinds of effect, trypsin solution was separately incubated with the same olive oil emulsion substrate at $\mathrm{p}^{\mathrm{H}} 7.5$ and $37^{\circ} \mathrm{C}$ for $20 \mathrm{~min}$ in a water bath shaker at 180 rpm. After the scheduled reaction time, $15 \mathrm{~mL}$ ethanol (95\%) was added to the mixture to eliminate trypsin activity and the liberated fatty acids were titrated. The result showed that no liberated fatty acid was detected, indicating that trypsin shows no direct hydrolysis effect on olive oil substrate. The increased liberated fatty acid content in the reaction mixture after reaction is only resulted from the improved lipase activity. Trypsin had been also found to have activation effect on aspartase [4]. Keiko \& Masanobu found that the activation of aspartase from Escherichia coli by trypsin required a few minutes to attain a maximal level, and hereafter the enzyme activity gradually decreased resulting in a complete inactivation in about 4 hours. Prior or intermediate addition of soybean trypsin inhibitor resulted in an immediate cessation of any further change in the enzyme activity, indicating the role of the limited hydrolysis of trypsin. Other researches also reported the activation effect of trypsin on some kinds of enzymes by limited hydrolysis. Shanthy et al. [14] found that trypsin-treated P-glycoprotein ATPase exhibited change in function. Trypsin-treated porcine procolipase, procollagenase, procarboxypeptidase $B$ and human matris metalloproteinase- 9 were also found to be activated [15-18]. Such activation of these enzymes is very complicated and may be linked to the changes of proteins in peptide chain and higher conformations. The active centre of the enzymes is affected substantially and rationally by these changes. So, appropriate limited hydrolysis of a protein or peptide will result in some beneficial change of the enzyme conformation, thus lead to the improved activity change.

\section{Lipase activity based on treatment conditions by trypsin}

The treatment conditions, involving the trypsin concentration (activity), treatment temperature, and treatment time and $\mathrm{pH}$ value mainly affect the activity of lipase via impact on the limited hydrolysis degree of lipase. Hence the effect of these factors on lipase activity was studied. The effect of trypsin concentration on lipase activity was carried out by incubating the lipase solution with $1 \mathrm{~mL}$ of trypsin solution from $0.5 \mathrm{mg} \mathrm{mL}^{-1}$ to $4 \mathrm{mg} \mathrm{mL}^{-1}$ at $30^{\circ} \mathrm{C}$ and $\mathrm{p}^{\mathrm{H}} 7.0$ for $30 \mathrm{~min}$. The maximum of the lipase activity reached about $759 \mathrm{U} \mathrm{mL}^{-1}$. It was found that at the trypsin concentrations lower than $1.5 \mathrm{mg} \mathrm{mL}^{-1}$, lipase activity increased as trypsin concentration was increased (Figure 1a), while as the trypsin concentrations were increased higher than $1.5 \mathrm{mg}$ $\mathrm{mL}^{-1}$, lipase activity was reduced markedly, indicating that excessive hydrolysis by trypsin can destroy lipase activity. The effect of treatment temperature on lipase activity was carried out by incubating trypsin with lipase solutions $\left(50 \mu \mathrm{L}\right.$ of lipase, $4 \mathrm{~mL}$ of $\mathrm{p}^{\mathrm{H}} 7.0 \mathrm{PBS}$ and $200 \mu \mathrm{L}$ of trypsin, at $5 \mathrm{mg} \mathrm{mL}^{-1}$ ) at $25^{\circ} \mathrm{C}, 30^{\circ} \mathrm{C}, 37^{\circ} \mathrm{C}, 45^{\circ} \mathrm{C}$ and $50^{\circ} \mathrm{C}$ for $30 \mathrm{~min}$ respectively. Figure $1 \mathrm{~b}$ shows the change of the lipase activity after 

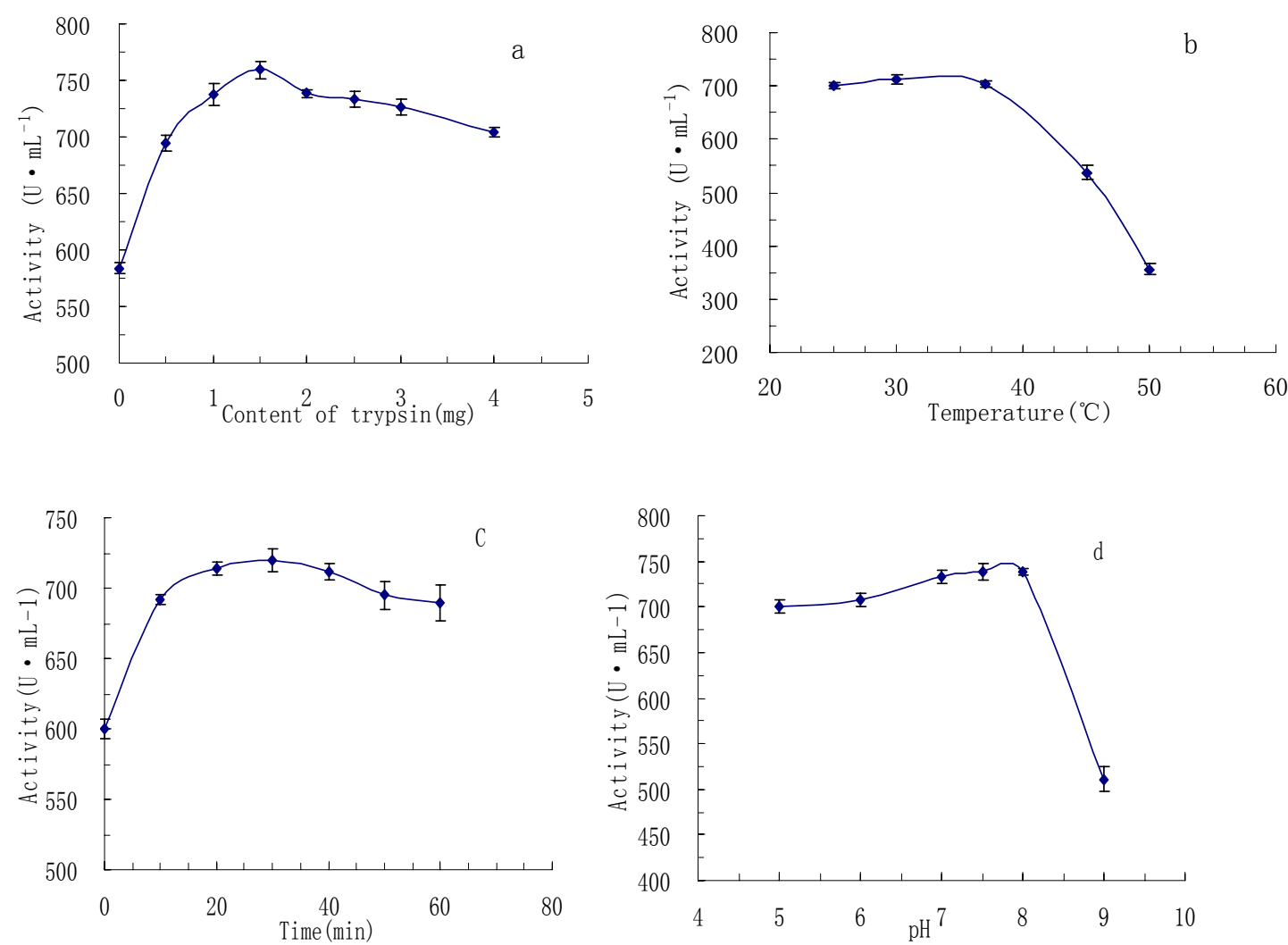

Figure 1: Effect of treatment conditions on the activity of lipase (a stands for the various trypsin concentrations; $b$ for various temperaturea; $c$ for the various minutes and $\mathrm{d}$ for various $\mathrm{p}^{\mathrm{H}}$ values) by Ziqin Liu et al.

trypsin treatment. The maximum activity of lipase appeared at $30^{\circ} \mathrm{C}$ (about $713 \mathrm{U} \mathrm{mL}^{-1}$ ). Lipase activity was found to be decreased obviously at the temperatures higher than $37^{\circ} \mathrm{C}$. The effect of treatment time on lipase activity was carried out by incubating the trypsin with lipase solutions $\left(50 \mu \mathrm{L}\right.$ of lipase, $4 \mathrm{~mL}$ of $\mathrm{p}^{\mathrm{H}} 7.0 \mathrm{PBS}$ and $200 \mu \mathrm{L}$ of trypsin, at $5 \mathrm{mg} \mathrm{mL}^{-1}$ ) at $30^{\circ} \mathrm{C}$ for $0-60 \mathrm{~min}$ respectively. The result is shown as Figure 1c. The maximum lipase activity appeared at the $30^{\text {th }} \mathrm{min}$ of the trypsin treatment (about $720 \mathrm{U} \mathrm{mL}^{-1}$ ). Extended treatment time showed a feeble increase in lipase activity. The effect of treatment $\mathrm{pH}$ value on lipase activity was also carried out by incubating the trypsin with lipase solutions $\left(50 \mu \mathrm{L}\right.$ of lipase, $1 \mathrm{~mL}$ of $\mathrm{PBS}$ from $\mathrm{p}^{\mathrm{H}} 5-9$ and $200 \mu \mathrm{L}$ of trypsin, at $5 \mathrm{mg} \mathrm{mL}^{-1}$ ) at $30^{\circ} \mathrm{C}$ for $30 \mathrm{~min}$ respectively. The result is shown as Figure 1d. It was found that lipase activity was affected markedly by $\mathrm{p}^{\mathrm{H}}$ value of the treatments. The maximum lipase activity appeared at - $\mathrm{p}^{\mathrm{H} 7.08 .0}$ (about $738 \mathrm{U} \mathrm{mL}^{-1}$ ). At the $\mathrm{p}^{\mathrm{H}}$ values higher than 8.0, lipase activity was observed to be reduced sharply and even lower than the activity of the native lipase $\left(584 \mathrm{U} \mathrm{mL}^{-1}\right)$ at $\mathrm{p}^{\mathrm{H}} 9.0$.

\section{Activity profiles of the trypsin-treated lipase at various $\mathrm{pH}$ values and temperatures}

The activity profiles of the trypsin-treated lipase at various $\mathrm{p}^{\mathrm{H}}$ values were assayed and compared with the native lipase by determining their activities in the buffers from $\mathrm{p}^{\mathrm{H}} 4-10$, at $37^{\circ} \mathrm{C}$, shown as Figure 2. The activity profiles of the trypsin-treated lipase at various temperatures were also assayed and compared with the native lipase by determining their activities at the temperatures from $25^{\circ} \mathrm{C}$ to $55^{\circ} \mathrm{C}$ at $\mathrm{p}^{\mathrm{H}} 7.0$, shown as Figure 3. Results showed that the optimum $\mathrm{p}^{\mathrm{H}}$ value of the trypsintreated lipase was at around 8.0, kept basically unchanged. This result is similar to the findings of Lee et al on the trypsin-treated aspartase, in which aspartase from Hafnia alvei was found to be activated by trypsin and the optimum $\mathrm{p}^{\mathrm{H}}$ of the trypsin-treated aspartase was also essentially unchanged [19]. The optimum temperature for the trypsintreated lipase was detected at around $40^{\circ} \mathrm{C}$, lower than the native lipase $\left(50^{\circ} \mathrm{C}\right)$, suggesting the much higher heat sensitivity of the trypsintreated lipase. The bell shape of the curves results from increasing rate of reaction at the lower temperatures and declining enzyme activity due to denaturation at higher temperatures.

\section{Kinetic properties}

Figure 4 shows the Lineweaver-Burk plots for the trypsin-treated lipase and native lipase. The Michaelis constant $\left(\mathrm{K}_{\mathrm{m}}\right)$, which corresponds

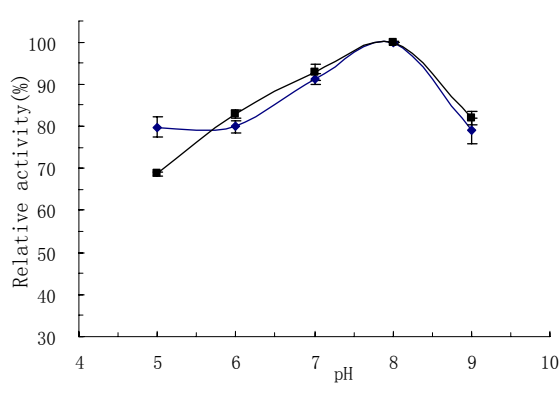

Figure 2: Activity profiles of the trypsin-treated lipase and native lipase at various $p^{H}$ values ( $\bullet$ stands for the trypsin-treated lipase and $\square$ for the native lipase) by Ziqin Liu et al. 
to substrate concentration that gives one-half of the maximum reaction velocity, was calculated from the negative reciprocal of the intercept with the $1 / \mathrm{s}$ axis. The $\mathrm{K}_{\mathrm{m}}$ values for the trypsin-treated lipase and native lipase were calculated as around $79 \mathrm{mg} \mathrm{mL}^{-1}$ and $100 \mathrm{mg} \mathrm{mL}^{-1}$ respectively. The $\mathrm{V}_{\text {max }}$ values for the trypsin-treated lipase and native lipase were calculated as around 56.18 and $49.75 \mu \mathrm{mol}$ fatty acid min ${ }^{1}$ respectively. The $\mathrm{K}_{\mathrm{m}}$ values signify the extent to which the enzymes have access to the substrates [20]. Smaller the $\mathrm{K}_{\mathrm{m}}$ values, higher the affinity of enzyme toward substrates. So the lower $\mathrm{K}_{\mathrm{m}}$ value for trypsintreated lipase indicates that hydrolysis by trypsin increases the affinity of the enzyme for olive oil substrate.

\section{Thermal stability}

The thermal stability of the trypsin-treated lipase and native lipase at $40^{\circ} \mathrm{C}, 45^{\circ} \mathrm{C}, 50^{\circ} \mathrm{C}$ and $60^{\circ} \mathrm{C}$ were studied and compared respectively, shown as Figure 5 and Figure 6 . It was found that the activity of both trypsin-treated lipase and native lipase at $45^{\circ} \mathrm{C}$ maintained unchanged basically within the almost whole period of incubation (90min). However, the decreased tendency was observed at the temperatures higher than $45^{\circ} \mathrm{C}$ for the trypsin-treated lipase and higher than $50^{\circ} \mathrm{C}$ for the native lipase. For both the trypsin-treated and native lipases, decrease in stability was found to be as the function of time. Hence the sequential deactivation based on three-step and two-step models was proposed for the deactivation of the trypsin-treated lipase at $50^{\circ} \mathrm{C}$ and $60^{\circ} \mathrm{C}$ respectively. These suggested three-step model and two-step model, represented as Equation (1) and Equation (2), were found to be correlated well with the experimental data (Figure 5). While at $45^{\circ} \mathrm{C}$, the data was found to fit well with a single-step (first-order) deactivation mechanism (Equation 3). The half-inactivation time for the trypsin-treated lipase at $45^{\circ} \mathrm{C}, 50^{\circ} \mathrm{C}$ and $60^{\circ} \mathrm{C}$ were calculated as

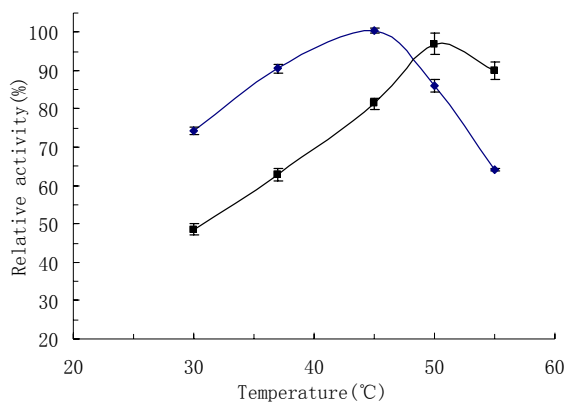

Figure 3: Activity profiles of the trypsin-treated lipase and native lipase at various temperatures ( stands for the trypsin-treated lipase and $\boldsymbol{\square}$ for the native lipase) by Ziqin Liu et al.

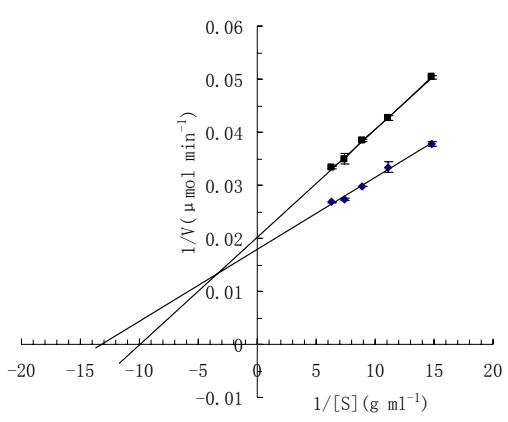

Figure 4: Lineweaver-Burk plot of trypsin-treated lipase and native lipase ( stands for the trypsin-treated lipase and $\mathbf{a}$ for the native lipase) by Ziqin Liu et al.

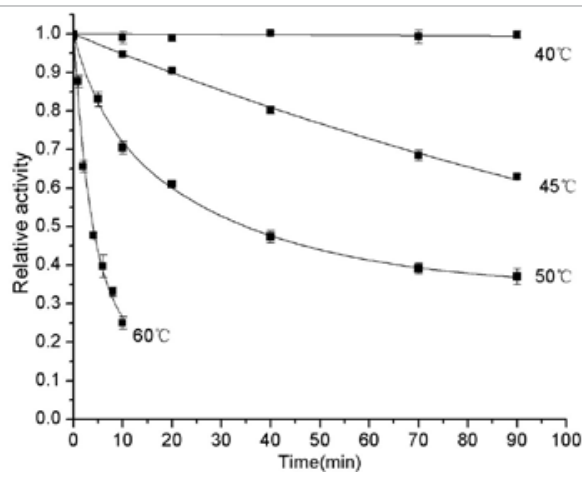

Figure 5: Deactivation kinetics of trypsin-treated lipase at $40,45,50$ and $60^{\circ} \mathrm{C}$ (experimental and predicted data-markers and lines, respectively) by Ziqin Liu et al.

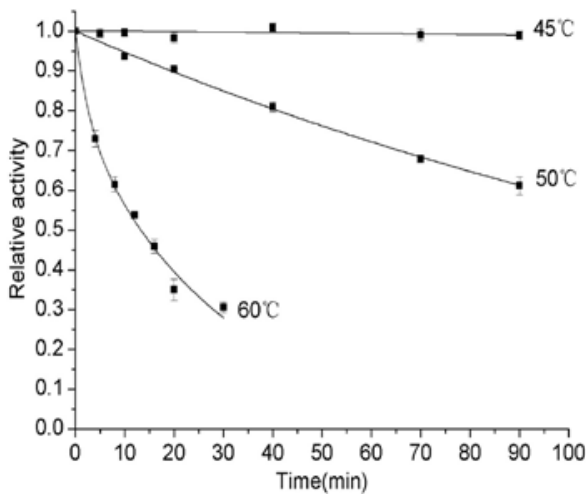

Figure 6: Deactivation kinetics of native lipase at 45,50 and $60^{\circ} \mathrm{C}$ (experimental and predicted data-markers and lines, respectively) by Ziqin Liu et al.

$131 \mathrm{~min}, 35.5 \mathrm{~min}$ and $4 \mathrm{~min}$ respectively. For the native lipase, the experimental deactivation dates exhibited as the function of time at 50 and $60^{\circ} \mathrm{C}$ and were adjusted based on a single step and three-step respectively (Figure 6). From Figure 6 the predicted data are found to be correlated well with the experimental data. The half-inactivation time for the native lipase at 50 and $60^{\circ} \mathrm{C}$ were calculated as $128 \mathrm{~min}$ and $13 \mathrm{~min}$ respectively. Consequently the thermal stability of the trypsintreated lipase is considered to be lower than the native lipase. Namely, limited hydrolysis of lipase by trypsin results in higher sensitivity to heat.

\section{Conclusion}

The activity, reaction kinetics and thermal-reliability of lipase are affected by trypsin hydrolysis. There into, the activity of the trypsintreated lipase is improved and the $\mathrm{K}_{\mathrm{m}}$ value is lower than the native lipase. The optimum temperature and thermal stability of trypsintreated lipase are lower than the native lipase.

\section{Acknowledgment}

The authors thank the Ministry of Science and Technology of the People's Republic of China (2010AA101505) for the financial support.

\section{References}

1. Hasan F, Shah AA, Hameed A (2006) Industrial applications of microbial lipases. Enzyme Microb Technol 39: 235-251.

2. Hung TC, Giridhar R, Chiou SH, Wu WT (2003) Binary Immobilization of Candida Rugosa Lipase on Chitosan. J Mol Catal B Enzym 26: 69-78. 
Citation: Liu Z, Huang H (2012) Activation and Characterization of Trypsin-Treated Lipase. J Food Process Technol 3:133. doi:10.4172/21577110.1000133

Page 5 of 5

3. Greenbaum LM, Hirshkowitz A, Shoichet I (1959) The Activation of Trypsinogen by Cathepsin. J Biol Chem 234: 2885-2890.

4. Keiko M, Masanobu T (1975) Trypsin-catalyzed activation of aspartase. Biochem Biophys Res Commun 67: 741-746.

5. Noboru Y, Masanobu T, Rikimaru H (1980) Studies on aspartase: Trypsinmediated activation releasing carboxy-terminal peptides. Biochim Biophys Acta 616: 319-328.

6. Onder A, Cevdet D (2010) Optimization of immobilization conditions of Thermomyces lanuginosus Lipase on styrene-divinylbenzene copolymer using response surface methodology. J Mol Catal B: Enzym 63: 170-178.

7. Zaidan UH, Abdul Rahman MB, Basri M, Othman SS, Abdul Rahman RNZR, et al. (2010) Silylation of mica for Lipase immobilization as biocatalysts in esterifcation. Appl Clay Sci 47: 276-282.

8. Chang SF, Chang SW, Yen YH, Shieh CJ (2007) Optimum immobilization of Candida rugosa Lipase on Celite by RSM. Appl Clay Sci 37: 67-73.

9. Vaidya BK, Ingavle GC, Ponrathnam S, Kulkarni BD, Nene SN (2009) Immobilization of Candida rugosa Lipase on poly(allyl glycidyl ether-coethylene glycol dimethacrylate) macroporous polymer particles. Bioresour Technol 99: 3623-3629.

10. Forde J, Vakurov A, Gibson TD, Millner P, Whelehan M, et al. (2010) Chemical modification and immobilisation of lipase B from Candida Antarctica onto mesoporous silicates. J Mol Catal B: Enzym 66: 203-209.

11. Jia B, Liu W, Yang J, Ye C, Xu L, et al. (2010) Burkholderia cepacia lipase gene modification and its constitutive and inducible expression in Pichia pastoris. Wei Sheng Wu Xue Bao 50: 1194-2011.

12. Kanasawud P, Phutrakul S (1993) Simple assay method for Lipase activity and analysis of its catalytic hydrolysis product in water-poor medium. Indian J Chem 32 B: 88-89.

13. Sá-Pereira P, Carvalho ASL, Costa-Ferreira M, Aires-Barros MR (2004) Thermostabilization of Bacillus subtillis CCMI 966 xylanases with trehalose: Study of deactivation kinetics. Enzyme Microb Technol 34: 278-282.

14. Nuti SL, Mehdi A, Rao US (2000) Activation of the Human P-Glycoprotein ATPase by Trypsin. Biochem 39: 3424-3432.

15. Wieloch $T$ (1985) Trypsin activation of porcine procolipase. Kinetics of activation and effects on lipid binding. FEBS lett 185: 63-66.

16. Stricklin GP, Jeffrey JJ, Roswit WT, Eisen AZ (1983) Human Skin Fibroblast Procollagenase: Mechanisms of Activation by Organomercurials and Trypsin. Biochem 22: 61-68.

17. Tan AK, Eaton DL (1995)Activation and Characterization of Procarboxypeptidase B from Human Plasma. Biochem 34: 5811-5816.

18. Duncan ME, Richardson JP, Murray GI, Melvin WT, Fothergill JE (1998) Human matris metalloproteinase-9: activation by limited trypsin treatment and generation of monoclonal antibodies specific for the activated form. Eur $\mathrm{J}$ Biochem 258: 37-43.

19. Lee MS, Choi KJ, Kwom SJ, Kang I, Ha J, et al (1999) Properties of trypsinmediated activation of aspartase from Hafnia alvei. J Biochem Mol Biol 32 573-578.

20. Kandasamy R, Kennedy L, Vidya C, Boopathy R, Sekaran G (2010) Immobilization of acidic Lipase derived from Pseudomonas gessardii onto mesoporous activated carbon for the hydrolysis of olive oil. J Mol Catal B: Enzyme 62: 58-65.

21. Shi XQ (2005) Enzyme Engineering. Beijing, Science Press: 281-282. 